\title{
Yoruba Folktales, the New Media and Postmodernism
}

\author{
Sesan, Azeez Akinwumi \\ Al-Hikmah University, Nigeria
}

\section{Introduction}

The complexity and dynamism of human society bring about innovation in the production, transmission, retrieval and performance of culture (low, high and popular). The advancement in technology as a result of postmodern social codes has given new impetus to discourse on the Yoruba verbal arts (with particular interest in Yoruba folktales).

Literary critics and folklorists have talked on the forms of Yoruba folktales, themes, taxonomy, sociological and literary significance in the contemporary society (see Dasylva 1999, Ben-Amos 1976; Finnengan, 1970; Sekoni, 1983, Bamgbose, 1969; and Iwara1985). Oral performance and folktales predate European civilization as shown in the archaeological and anthropological findings of the Western scholars. It is therefore uncharitable to history to claim that Africa had neither art nor literature before the European civilization.

The concern of literary critics, folklorists and culture critics should be committed and astute in the investigation into how the past and the present inter-relate in a "global village". Culture is dynamic and adaptive to the prevailing social and sociological conditions. Scholars and critics of cultural studies (with absolute inclusion of folktales) should respond positively to the challenges posed by Olorunyomi (190) that:

While noting that contemporary society is far removed from the era of pristine orality as a literary and human communicative mode, we posit that the concept of orality continues to shape scholarly discourse besides informing creative production. How then do aspects of the past inform the present, and also assist in better comprehension of this time interval in aesthetic epistemological terms. How do social and technology 
development affect aesthetic and literary production and appreciation?

Reacting to the challenge, critics are expected to re-visit the ethical and aesthetic values of folktales in relation to the emergence of the new media. It is expected that improvement in human civilization and unbridled technological advancement will bring about modification in cultural productions. The new media have affected the production and performance of Yoruba folktales, particularly as shown in the performer- audience relationship. The performance of Yoruba folktales is now mediated thereby becoming deficient in immediacy and spontaneous reactions that characterize pristine orality.

The question posed by Olorunyomi that "how do social and technological developments affect aesthetic and literary production and appreciation" is thereby reacted to. Yoruba folktales like the informing culture (Yoruba culture) have not adequately appropriated the resources of the new media. The social and technological developments affect aesthetic and production of Yoruba folktales in the following ways:

- Disruption of space and time: Yoruba folktales are performed within specific spatial and temporal spectra. Performance space of Yoruba folktales is physical, psychological and social and this justified the significance of folktales in the socialization process of a Yoruba child. The time reflected in the performance of Yoruba folktales is the synergy of now, then and later. With the emergence of the new media, the physical and the social space have been disrupted owing to the factors of modernity, innovation and technology.

- Distortion of psycho-social relationship: This is related to the first. The physical, visual and psychological interaction between the performers of the folktales and the ir audience are distorted in the new media. The kinesis of performance that registers the messages of the tales in the psyche of the audience suffers irredeemable loss in the new media.

- Rupturing of cognition, retention and recall: In the contemporary Yoruba society, children and even many adults in the rural and urban centers cannot perform folktales. They find it difficult to recall folktales previously learnt because of the poor cognitive base in the folktales culture of their people. The dramatic performance of folktales in a physical setting enhances retention and recall. 
What can be realised from the above points is that Yoruba literary and cultural arts (folktales inclusive) have responded poorly to the social and technological developments ushered in by postmodernism.

In the context of this paper, folktales are taken as the aggregate of oral narratives ( myths, legends and animal stories) that are peculiar to a culture. This form of oral art is not alien to Africa and it has been performing utilitarian functions of entertainment, education and socialisation. The evolution and revolution in information and communication technologies provide a motivation for the emergence of the new media. In the context of this paper, new media are regarded as the means of information transmission and dissemination that surpass the oral and the written media. In this instance, the new media include internet, mobile telephony, television and other forms of digital communication. The complex nature of the modern society is a reflection of the traits of postmodernism. In the context of this paper, postmodernis $m$ is seen as the situation of the advancement in human knowledge owing to the advancement in science and technology. The goal of postmodernism is the change in human society and this change has affected cultural production and consumption such as folktales.

\section{Yoruba Folktales: Towards a Taxonomy}

The open-endedness of African oral narratives, particularly Yoruba folktales has encouraged various scholarly contributions on their taxonomy. Different parameters have been adopted by scholars and critics in carrying out the "classificatory paradigms of African oral narrative". Some western scholars began the taxonomy of African oral narratives as a mere quest into knowing the rudiments of African literature that they know little or nothing about. A reasonable number of African scholars and critics ventures into the rigours of taxonomy of African oral narratives as a quest for "alter-native" tradition in the discourse of African literature. Despite the "genuine" interest of these earlier scholars in doing the taxonomy of African oral narratives, there have been some inadequacies and incompetencies in their classification of oral narrative in Africa. Dasylva (11) observes:

Appreciable efforts were made in the past by critics which have yielded very promising results with different classificatory models. Unfortunately, none of these models is considered sufficiently appropriate for the African oral narrative. The problems are not unconnected with theoretical inadequacies traceable largely to the protean forms, the high 
mobility and/or fluidity propensity of the generic constituents, and the complexity of functions of the African oral narrative.

These earlier scholars have used different templates - plot or structure, thematic pre-occupation and characterology in doing the taxonomy of African oral narrative. Either by implication or in an expressed term, various scholars - Ruth Finnegan (1970), Ayo Bamgbose (1969), William Bascom (1943 and 1965), Alexander U. Iwara (1985), Tunde Ogunpolu (1986 and 1990) and Ropo Sekoni (1979, 1982 and 1983) among others have made laudable contributions towards the taxonomy of African oral narratives and by extension, Yoruba folktales.

In his study, Bamgbose (1969) classified the themes of Yoruba folktales into three - "moral stories", "Tortoise stories", and "why stories". What is however observed in this classification is that Yoruba folktales have been vaguely classified. Critics like Dasylva (1999) have observed this attempt by Bamgbose "to create a generalized dichotomy between the "tortoise" and "moral stories" lack a fundamental bas is".

Sekoni (1983) critiques Yoruba folktales along the line of character - types or rather characterology. His submission is an extension of Claude Bremond's (1966) classification of character types in folktales. Unlike in Bremond's (1966) study in which character types in folktales are categorised into three (amelioration, degradation and stagnation), Sekoni (1983) gives four character - types in folktales. He (Sekoni 5) writes:

Yoruba folktales, regardless of whether the actors, i.e. characters are animate or inanimate, and of whether character's actions are accomplished by overt moralizing or not, thus fall in four fictive categories; heroic, non-heroic, anti-heroic and a-heroic.

Sekoni's observation is a bit all-inclusive because it involves both human and nonhuman characters of folktales. This opinion is corroborated because fictive characters (human or non-human) move in-and-out of a fictive territory - human kingdom, animal kingdom, streams and the land of ghomids.

In doing the taxonomy of folktales, Ogunpolu (1986) uses the spectrum of performance. Based on its preference of the performance quality of folktales in their entirety, Ogunpolu (1986) identifies seven constituents - (i) function of tale in community; (ii) narrator; (iii) audience; (iv) traditional or local name of tale; (v) content; (vi) character, and (vii) structure. At the level of genres, the critic 
(Ogunpolu) identifies two forms of Yoruba verbal arts - Itan (prose) and Ewi (poetry). For clarification, he further sub-divides Itan (prose) into four Feyikogbon (moral), Yenwo (divinatory), Orirun (origin/myth/legend/aetiology), and Amusagbara (incantatory). The main shortcoming of Ogunpolu's taxonomy is over-generalization. For instance, Yenwo (divinatory) and Amusagbara (incantatory) are more qualified as poetry because of their use of imagery, symbols and figurative expression to convey their messages.

In another study, Iwara (1985) broadly classifies folktales into two ( non - fiction and fiction). In his study, fictional stories have seven sub-categories which include divination stories, hunter stories, enfant terrible stories, Yo-stories, co-wives' intrigues, explanatory and moralizing stories, and transformation stories. Under non-fictional stories, in the opinion of Iwara, there are historical, creation and origin stories. The perceived shortcoming in this classification is the critic's separation of historical stories from creation and origin stories. In most situations in Yoruba folktales, historical stories are intricately linked with creation and origin stories. In Yoruba loric traditions, most creation and origin stories have historical basis.

Bascom (1943), in his taxonomy identifies two forms of narrative in Yoruba oral traditions. These two classes are myths (Itan) and folktale (Alo). Myths are more valued than folktales because they are more factual and historically true and reliable. On the other hand, it is believed that folktale is fictional and factually undependable. By locating the two forms (itan and alo) in the recital of Ifa verses, the critic (Bascom) creates a critical loop hole for his study. In Yoruba cultural beliefs, many lores, myths and legends are present in Ifa literary corpus. By tracing the origin of itan (myths ) and alo (folktale) to Ifa literary corpus, Bascom has taken unmerited and uncommendable course in his classification of oral narratives in Africa.

Despite various submissions on the taxonomy of African oral narratives, particularly Yoruba folktales, there is still a continuous search for an "authentic" taxonomy of Yoruba folktales. This situation is expected to reach its full maturation when African (oral) literature as a whole is canonized to fellowship among the committee of world literatures.

\section{Yoruba Folktales: The Art and its Performance}

Like dramatic art, the performer of folktales relies on the facilities of his/her voice and body. The way a performer activates and manipulates his/her voice and body helps to sustain the interest of the audience in the performance. Though there is a 
mutual collaboration between the performer of folktales and his/her audience, there is a need for the skillful mastery of the content and the technique of performance. There is therefore an intricate relationship between what and how in the performance of Yoruba folktales.

During the performance of Yoruba folktales, words are not formless, baseless, passive and void. They rather contribute to the full realization of the subject matter and thematic significance of the folktales. The performer of folktales therefore relies on the verbal and non-verbal gestures for the purpose-driven utilization of words and language aesthetics during the performance. Words in the performance of folktales therefore make use of psycho- stylistic devices for active participation of the audience and the performer. Ong (47) observed the signif icance of words in oral art. She writes:

Words acquire their meanings only from their always insistent actual habitat, which is not, as in a dictionary, simply other words, but includes also gestures, vocal reflections, facial expression, and the entire human existential setting in which the real, spoken words always occur.

It can thus be said that words are functional in the performance of folktales and other oral narratives.

Apart from the utilization and manipulation of the body and voice of the performer, there is also a need for the significant manipulation of the performance space. In the traditional Yoruba society, the performance space of Yoruba folktale is triangular, corresponding and interactional between the audience and the performer. The model of the traditional performance space of Yoruba folktale is given in the framework below:

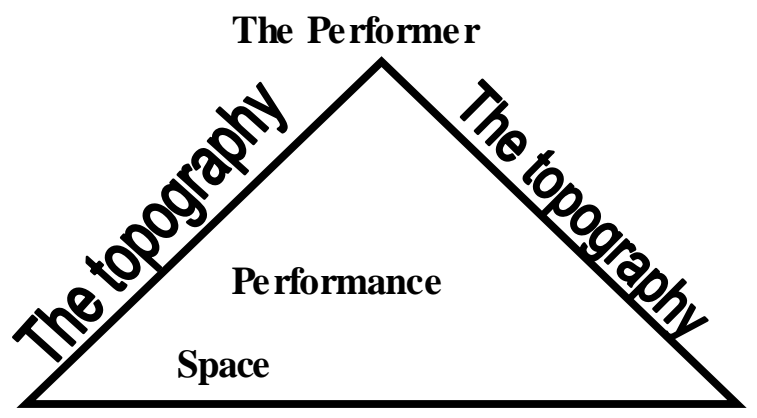

The audience 
The performance space of Yoruba folktales is collapsible to afford the performer and the audience the opportunity of physical contact and verbal exchanges. An experienced performer makes use of other forms of performing arts such as songs, drumming and dancing to foster mutual and physical interaction between him/her and the audience. The plot structure of Yoruba folktales like every other oral narrative is elastic, mutable and flexible. The sociology, psychology and psychosocial variables of the performer and/or performance influence the plot structure of the folktales and other oral narratives. These factors further enhance the dynamism and flexibility observed in the performance of oral literature. Osundare (5) intoned that:

And owing to the dynamic, flexible, and ever-growing nature of oral literature, this telling may enjoy varying virtuosities in the hands of different raconteurs. In fact, it may be said that no two narrators tell the same folktales exactly the same way, since situational factors such as type of audience, their reaction, venue of performance, and mood and temperament of the narrator are anything but constant.

During the performance of folktales, it can be said that the setting, the audience and performer's factors influence the plot and characterization of the story. Any folktale performed reflects the flora and fauna of its performance context.

\section{Yoruba Folktales, New Media and the Postmodernist Challenges}

Digital technology, information superhighway, globalization and destabilization of communalism in favour of individualism are the progeny of postmodernism. The consequence of all these is the change in the psychodynamics of the literary and cultural productions.

In literary, sociological and philosophical discourses, postmodernism has been critiqued. The significant contributions of Roland Barthes, Wolfgang Iser, Charles Jeneks, Jack Derrida and Susan Sontag in the promotion and advancement of postmodernist tenets cannot be overlooked. While attempting the description of postmodernism Bamisaiye (11) wrote:

In this paper the author attempts a definition of postmodernism as a philosophy of revolt against totalitarianism and rationality advocated by modernist philosophy. Postmodernism advocates individual autonomy, and voluntariness. It sees human nature as ambivalent and human moral action as contingent upon the situation for moral action as well as society. Epistemologically, 
postmodernism is against a set rational basis for knowledge either in content or its methodology.

With the domination of postmodernist tradition, the faint pristine past of Africa is being eroded away. The emergence and sustenance of postmodernist tradition are as results the following factors:

\section{Urbanization}

In the contemporary Yoruba society, urban centres are springing up on daily basis. There is a massive movement of people from the rural settings to the urban centres. It is disheartening to see how many "agbo ile" (family compound) give way to filling stations, shopping complexes and other business centres. The consequence of this is that the convivial gathering of people for folk performances and communal activities is not easy to come by. Urbanization promotes individualism which is alien to African tradition. This urbanization is also extended to internet communities and other virtual interactions.

\section{The Arabic and Euro-modernist Religions}

The coming of the two religions (Islam and Christianity) influences the socio-cultural orientations of Africans generally and the Yoruba in particular. These two religions condemn some Yoruba cultural practices as being against the commands of Almighty God. In the contemporary Yoruba society, churches and mosques come up with so many programmes that make it practically impossible for the performance of folktales.

\section{Print and Digital Technologies}

The invention of writing and printing technologies negatively impacted on the production and consumption of oral text. The visual and physical contact between the performer and the audience is removed. The text is mediated through the medium of book. There is thus a shift from oral culture to "book culture" and this situation is referred to as "secondary orality" by Walter Ong (1982). Osundare (2) provides a framework showing the difference between the oral text and the written text.

\begin{tabular}{|l|l|l|}
\hline & \multicolumn{1}{|c|}{ Oral } & \multicolumn{1}{c|}{ Written } \\
\hline Mode of Production & Voice & Hand \\
\hline Quality of Production & Utterance & Text \\
\hline Mode of Reception & Ear & Eye \\
\hline
\end{tabular}




\begin{tabular}{|l|l|l|}
\hline Immediate Impact on Receptor & Heard & Seen \\
\hline Basic Linguistic Elements & Phoneme & Grapheme \\
\hline
\end{tabular}

The framework shows that the oral and the written texts project different traditions. The evolution and revolution in digital technologies further change the psychodynamics of oral texts. Internet and satellite broadcasting further promote individualism that encourages people to be in the comfort of the ir homes instead of "public centres" for the performance of folktales.

\section{Wes tern Education}

The introduction of western education to Africans has some considerable impacts on some traditional practices. In the curriculum of literature, much emphasis is placed on European literature based on the wrong assumption that Africa had no literature before the European incursion on the continent. Folktales suffer some neglect in the process. Some Europeans that later did the collection of African folktales did so in a foreign tongue (English, French and German, etc.) and with no relative objectivity.

The concern, therefore, is the assessment of the outcome of the postmodernist influence on the survival of Yoruba folktales. The folktales in Yoruba land have not gone into total extinction. There is submergence of folktales in other art forms (literary and performing) such as music, drama, prose fiction, poetry and film. It is not uncommon to see folkloric traits in the performance of music and film genres. Fela Anikulapo, beautiful Nubia, Ayinla Omowura and Orlando Owoh are noted for the use of folkloric elements in their songs. It is however expected that Africa should react proactively to the challenges of postmodernism or are we really saying that postmodernism is suicidal to Africa? Do we say that Africa has not learnt how to manage the postmodernist challenges? Answers are provided to these and similar questions with the view of Layiwola (17) that:

The world around us in growing more complex by the day; reality is changing or mutating at an amazing speed, such that the language and images to represent that reality must continue to mutate with it. In the process, boundaries are bound to emerge and re-emerge.

Postmodernism has only encouraged the emergence of new boundaries and the reemergence of the old boundaries into prominence. This, consequently, has been encouraging the prominence of virtual boundaries over physical boundaries. In 
short, postmodernism indicates "a new direction from the previous one as observed by Lyotard (47-8) that:

The 'post-' of postmodernism has the sense of a simple succession, a diachronic sequence of periods in which each one is clearly identifiable. The 'post' indicates something like a conversion: a new direction from the previous one.

From the viewpoints of Layiwola (2010) and Lyotard (1993), the questions raised can thus be answered that postmodernism is not totally suicidal to Africa and that Africa has not learnt how to manage the postmodernist challenges.

\section{Yoruba Folktales, New Media and Postmodernism: Managing the Trends}

Yoruba folktales and postmodernism can be properly managed if there is an indepth understanding of the factors militating against (re)production of African oral/verbal art in the new media. The problem militating against the (re) production of Yoruba oral/verbal art is congenital and systemic. It is a common practice in Africa that we do not appreciate what we have until it is lost. In the African pristine past, verba//oral art and its performer were acknowledged and given due recognition as agent(s) of socialization and education. In this direction, Sesan ( 8) has observed that:

In the pre-literate Yoruba societies, folktale narrators can therefore be seen as performers, socialization agents, epitome of knowledge and experience, social commentators and teachers of moral. Combining all these roles, folktale narrators are highly respected by the children .

The above situation is no more available in the contemporary Yoruba societies. "Book wisdom" has overrun and overtaken the native wisdom of the elders as evident in the ir language aesthetics (proverbs and local idioms), verbal arts and folk performance.

The largest percentage of Yoruba elders has lost the full mastery of the folktales as a result of Europeanization of African culture and cultural practices. The culture of the contextual performance of folktales has gone into extinction in the contemporary Yoruba societies because modern living supports and encourages individualism premised upon "me and my family" syndrome. The adults, being regarded as the epitome of knowledge also rely on the "book knowledge" for the performance of folktales. The present writer was surprised at the cultural misnomer 
during one of his field investigations on Yoruba folktales. In a village at Moniya in Akinyele Local Government Area of Oyo State, a village head, who happened to be the performer of some folktales, became uncomfortable during the performance. He lost the track of the tale being narrated and in the process asked one of the children among the audience how that particular tale has been narrated in the ir Yoruba text (Alawiye) by Late J.F. Odunjo. This is a sign that Yoruba folktales have not been properly preserved for posterity.

The problem becomes more compounded with poor formulation and implementation of literature-in-English Curriculum in Nigeria. The syllabi of Literature-in-English in Nigerian schools place some considerable emphasis on Non-African literature. Works of Shakespeare are made compulsory in the objective test. In these syllabi, there is no space for oral literature. This phenomenon shows that Africa, in general and Nigeria, in particular is not ready for the globalization of her literature. The same phenomenon has been transformed to the language and literary studies in Yoruba. Adequate attention is not given to literature written in Yoruba language. The present writer had the opportunity of offering courses in Yoruba Language and Literature-in-Yoruba and sat for the same in the Senior Secondary Certificate Examination. It is however disheartening to say that this is no more available in our school system today. Apart from this, the country has poor, e-learning culture. The culture of e-learning will enhance adaptation of literature written in indigenous language into the new media. With the latest technological revolution which brought into limelight the introduction of World Wide Web orality is presented through the internet (Ibitoye and Sesan 91). It is quite unfortunate to see that Nigerians have not responded meaningfully to the opportunities offered by the new media.

New media, one of the progenies of postmodernism, give a new dimension to the (re)production and consumption of literature. It is the expectation in Nigeria to manage the latest development. The view of Schaniel (493) is therefore corroborated that:

The new technology may create change in society, and that the direction of change is determined by the nature and function (use) of that technology in the adopting culture.

Nigeria like every other third world country, is the adopting culture of the new technology. In Nigeria, the function (use) of the new media does not favour worthwhile literary production and consumption. The new media have not been properly utilized to foster the survival of folktales. These trends can be properly managed by correcting the abnormalities in our cultural system. The informing 
culture (Yoruba culture) is threatened by the upsurge in postmodernist challenges of the new and globalized media.

\section{The Way Out}

Our culture and cultural practices can still survive the challenges of postmodernism with strong political will and dogged determination. The attitude of Nigerians to their culture and cultural practices needs to be corrected. There should be intense national re-orientation for Nigerians on the need for cultural renaissance. The culture of a nation identifies such nation among the committee of nations. With this, Nigerians will show renewed interest in their culture and valuable cultural practices.

Having done this, folklorists and literary experts should be encouraged to do a fresh reading (collection, analysis, transcription and storage) of folktales in Nigeria. These experts should also work in collaboration with computer animation specialists for animation. This approach will "create change in society". This opinion is given because Nigerians have cultivated a good "watching culture". These animated folktales can become source of income for individuals and the government through exportation. Tom and Jerry and The Lion King are sorts of folktales in America. Today, in Nigeria, these animated folkloric stories are household means of entertainment among the Nigerian children. Nigerians, therefore, need to respond to the opportunities offered by the facilities of computers. Computer technology has made animation very sophisticated and complicated and at the same time simplified, easier, faster and less expensive (Ogbonna, 2011:219).

Literature curricular (in English and Yoruba Language) should be redesigned. There should be adequate consideration for oral literature in the primary and secondary schools curricular of literature. This will ensure the continuity of the oral literary culture. We should appreciate what we have and preserve our culture for posterity.

\section{Conclusion}

This study has critically examined the nature of Yoruba folktales. It is discussed in the paper that Yoruba folktales are triangular in nature showing the relationship between the performer and the audience. The paper is of the opinion that postmodernism is not the problem with the survival of Yoruba folktales but the problem is the inability of Nigerians to manage the challenges posed by postmodernism. 


\section{References and notes:}

Bamgbose, Ayo. "Yoruba Folktales ". Ibadan, vol. 27, 1969: 6-12.

Bamisaiye, Remi. "Some Postmodernist Philosophical Considerations in the Teaching of Literature", in Ibadan Journal of Humanistic Studies, No. 8 1998: 11 - 20.

Bascom, W. R. "The Relationship of Yoruba Folklore to Divining", in Journal of American Folklore, vol. 56. 1943.

Ben-Amos, D. " Analytical Categories and Ethnic Genres" Folklore Genres, Ben-Amos, D. (ed). Austin: University of Texas Press, 1976: 215-241.

Dasylva, Ademola. Classificatory Paradigms in African Oral Narrative.Ibadan: Ibadan

Cultural Studies Group, 1999

Finnegan, Ruth. Oral Literature in Africa. Oxford: Oxford University Press. 1970.

Ibitoye, W.A. and Sesan, A.A. "Re-Positioning Oral Literature Via E-Learn ing in Schools", in Journal of English Language and Literary Studies. Vol 1, No 1, 2007: 87 - 95.

Iwara, A. U. " Unity in Diversity of West African Folktales". A Seminar Paper presented at The Institute of African Studies, University of Ibadan, 1985.

Layiwola, Dele. A Place Where Three Roads Meet: Literature, Culture and Society. Ibadan: Ibadan University Press, 2010.

Lyotard, J. "Note on the Meaning of 'Post', in Thomas Doherty (ed.) Postmodernism: A Reader: New York: Colu mbia University Press, 1993 : 47 - 50.

Ogbonna, C.A. "The Computer as a Panacea to the Challenges in the Production of Cartoon Animation Films in Nigeria" in Duro Oni and Sunday Enessi Ododo (eds.) Technical Theatre and the Performing Arts in Nigeria. Lagos: NANTAP, 2011: 219-241.

Olorunyomi, Sola. "Orality as Text in Mutation", in Aderemi Raji - Oyelade and Oyeniji Okunoye (eds.) The Postcolonial Lamp. Ibadan: Bookcraft 2008: 190 - 201.

Ong, Walter, J. Orality and Literacy: The Technologization of the Word. London and New York: Routledge, 1982.

Osundare, Niyi. "From Oral to Written: Aspects of Socio-Stylistic Repercussions of Transition; in Journal of African and Comparative Literature. No 1, 1981: 1 - 13.

Schaniel, W.C. "New Technology and Culture Changes in Traditional Societies", in Journal of Economic Issues, Vol. 2, 1, 1988: 491 - 502.

Sekoni Ropo. "The Narrator, Narrative Pattern, and Audience Experience of Oral Narrative Performance", in Okpewho, I.( ed.) The Oral Performance in Africa. Ibadan: Spectrum Books, 1990.

Sekoni, Ropo. "Towards a new Taxonomy of Yoruba Oral Prose Fiction”. A Seminar Paper presented at the Department of Literature in English, Obafemi Awolowo University, Ile- Ife, 1983.

Sesan Azeez Akinwumi. "Socialization of a Yoruba Child in the Era of Postmodernism: Implications for Socioeconomic Development in Nigeria". A Paper Presented at 2011 International Conference of Faculty of Social Science, Obafemi Awolowo University, Ile-Ife, Nigeria. 


\section{Summary}

\section{Yoruba Folktales, the New Media and Postmodernism}

\section{Sesan, Azeez Akinwumi}

\section{Al-Hikmah University, Nigeria}

The Yoruba pristine orality in its entirety has been given new directions with the popularity of the postmodernist tenets as shown in the utilitarian use of the new media in literary production, dissemination and consumption. This paper seeks to examine how the postmodernist material and immaterial culture have influenced the literary and cultural values of Yoruba folktales. Data for this study are gathered through field investigations at Omi Adio, Aba Ebu ( Moniya) and Badeku, all in Oyo State, Nigeria. Archival documents on the subject matter are also consulted. It is observed that apart from affecting the physical and cultural landscapes of Africa, postmodernism/new media has also affected the literary landscape of the continent. It is concluded that Africa has not effectively utilized the resources of new media to promote the vitality of folktales. It is recommended that the teaching of Oral Literature should be made compulsory in the curricula of primary and secondary schools in Nigeria.

Key Words: Postmodernism; folktales; taxonomy; performance, art 